\title{
Perioperative outcomes of the patients treated using laparoscopic cholecystectomy after emergent endoscopic retrograde cholangiopancreatography for bile duct stones: Does timing matter?
}

\author{
Rahman Şenocak, M.D., S Süleyman Utku Çelik, M.D., \\ (1) Şahin Kaymak, M.D., 이 Oğuz Hançerlioğulları, M.D.
}

Department of General Surgery, University of Health Sciences Gülhane Training and Research Hospital, Ankara-Turkey

\begin{abstract}
BACKGROUND: There is no consensus on the optimal timing for laparoscopic cholecystectomy (LC) after emergent endoscopic retrograde cholangiopancreatography $(E R C P)$ for suspected choledocholithiasis. Although certain data suggest that an early interval or single-stage treatment by LC, together with laparoscopic bile duct exploration, has more favorable outcomes, delayed LC is most often preferred as the standard treatment of patients with gallstones and choledocholithiasis following ERCP due to lack of experience, necessary instrumentation, or organizational restrictions. This study aims to compare the effects of different time intervals between ERCP and LC on perioperative outcomes.
\end{abstract}

METHODS: In this paper, preoperative and postoperative data from consecutive patients who were treated for common bile duct stones with emergent ERCP and then underwent LC were reviewed retrospectively. To evaluate the impacts of different time intervals on outcomes, patients were classified into three groups according to the duration from the last ERCP to LC: within two weeks (Group I), between 2-6 weeks (Group 2), and over six weeks (Group 3).

RESULTS: This study involved an analysis of 67 patients with a mean age of 52.8 years. Overall conversion rate was $20.0 \%$ in Group I, $25.0 \%$ in Group 2, and $13.6 \%$ in Group $3(p=0.646)$. The rate of conversion to open surgery was $25.0 \%$ in male patients and I4.2\% in females. In addition, no significant difference was found between the groups concerning gender, comorbidities, laboratory and gallbladder features, operation time, and length of the hospital stay. The perioperative complication rate was found to be $17.9 \%$; however, there was no significant difference between the three groups.

CONCLUSION: Our results support that LC after ERCP is more complex and has higher conversion rates than LC for uncomplicated cholelithiasis. Although no significant effect of different time intervals between ERCP and LC on perioperative outcomes was demonstrated in patients with common bile duct stones concomitant with cholelithiasis, the 2-6 weeks after ERCP is a critical period for conversion to open surgery. It is recommended that LC after ERCP should be performed in the early period, considering that serious complications may occur in the late period and recurrent biliary attacks may occur.

Keywords: Choledocholithiasis; cholelithiasis; complication; endoscopic retrograde cholangiopancreatography; laparoscopic cholecystectomy.

\section{INTRODUCTION}

Approximately $15 \%$ of the patients with cholelithiasis have simultaneous bile duct stones, whereas $95 \%$ of the patients with bile duct stones have cholelithiasis. [" Decompression of the common bile duct (CBD) and removal of stones by en-

\footnotetext{
Cite this article as: Şenocak R, Çelik SU, Kaymak Ş, Hançerlioğulları O. Perioperative outcomes of the patients treated using laparoscopic cholecystectomy after emergent endoscopic retrograde cholangiopancreatography for bile duct stones: Does timing matter? Ulus Travma Acil Cerrahi Derg 2020;26:396-404.

Address for correspondence: Süleyman Utku Çelik, M.D.

Sağlık Bilimleri Üniversitesi Gülhane Eğitim ve Araştırma Hastanesi, Genel Cerrahi Kliniği, Ankara, Turkey

Tel: +90 312 - 3042000 E-mail: s.utkucelik@hotmail.com

Ulus Travma Acil Cerrahi Derg 2020;26(3):396-404 DOI: 10.14744/tjtes.2020.9440I Submitted: II.03.2020 Accepted: 17.04.2020 Online: I3.05.2020

Copyright 2020 Turkish Association of Trauma and Emergency Surgery
} 
doscopic methods are commonly accepted treatment methods in symptomatic and obstructive CBD stones. Various surgical methods, such as open or laparoscopic cholecystectomy (LC) with CBD exploration, laparoscopic-endoscopic rendezvous (LERV) technique or two-stage LC either before or after endoscopic sphincterotomy (ES) with endoscopic retrograde cholangiopancreatography $(\mathrm{ERCP})$, are preferred when treating bile duct stones. ${ }^{[2]}$ Although the outcomes of single-stage laparoscopic CBD exploration and LERV technique may be alternative or comparable to combined methods. ${ }^{[3,4]}$ Currently, the most common procedure in many countries is the elective LC performed after preoperative $\mathrm{ERCP}$ and $\mathrm{ES} .^{[5]}$

For patients with residual stones in the gallbladder after CBD stone removal with ERCP, the subsequent management of the gallbladder is still a subject to debate. While planned cholecystectomy after the wait-and-see policy or ES is recommended for residual stones in the gallbladder after endoscopic stone removal, there are also recent articles that suggest the administration of early cholecystectomy after ES to all patients with $\mathrm{CBD}$ stones and gallstones accompanied by co-morbidities or with stones eligible for surgery ${ }^{[6]}$ In the case of the wait-and-see policy after ES, 10-50\% of patients may develop recurrent biliary events (RBE), so to decrease RBE rates, cholecystectomy may be performed as early as possible after ERCP rather than waiting for a long period of time. Early cholecystectomy recommended in 7-14 days after the initial admission has been shown in the literature to be cost-effective, to improve clinical outcomes, and to be a superior treatment regardless of ERCP in the treatment of acute cholecystitis and mild biliary pancreatitis. ${ }^{[7,8]}$ However, the generalizability of this evidence to post ERCP patients is unproven. Moreover, previous studies have shown that the rate of conversion from laparoscopic to open cholecystectomy after a previous ES is as high as $8 \%$ to $55 \%$ versus less than $5 \%$ in patients with uncomplicated cholelithiasis. ${ }^{[4,9-13]}$ Although there is no consensus regarding the optimal timing for cholecystectomy following therapeutic ERCP, in many countries, LC after ES is still practically performed after 4-6 weeks of delay. Reasons for this delay include logistical reasons, the assumption of full recovery from an acute illness before surgery and expecting inflammatory response to subside after six weeks. ${ }^{[8,9,11]}$

In various studies and reviews, the interval from ERCP to LC has ranged from days to months, and conflicting results have been obtained. While some researchers advocated that an early interval led to more favorable outcomes (fewer conversion rates, less perioperative complications and length of hospital), some researchers found that time intervals had no influence on the course of laparoscopic procedure. ${ }^{[6-8,11-13]}$ The present study aims to compare the effects of different time intervals between ERCP and LC on conversion to open cholecystectomy and perioperative outcomes.

\section{MATERIALS AND METHODS}

This study was approved by Gulhane Military Medical Academy Ethics Committee (approval number: 50687469|49|-|46-16/1648-436) and was conducted in accordance with the 1964 Helsinki Declaration and its later amendments. This study included 18-year-old or older patients who underwent a successful ERCP and endoscopic stone removal operation due to choledocholithiasis, had radiologically proven residual gallbladder stones, and underwent LC at the Department of General Surgery from among 550 patients who were diagnosed with cholestasis and underwent emergent ECRP between 2013 and 2016 at the Department of Gastroenterology. Patients who were not suitable for surgery (ASA V), and patients who had stones that could not be removed through ERCP and therefore had to undergo open surgery and ductal exploration or percutaneous transhepatic biliary drainage were not included in the study (Fig. I).

Demographics, ultrasonographic features of the gallbladder, such as thickness, content, and stones, ERCP notes, conversion rate and reasons, operative time, bile duct injuries, the need for a drain, and postoperative length of hospital stay were recorded. Complications were graded according to the Clavien-Dindo classification system. ${ }^{[14]}$ On-admission biochemical parameters, including leucocyte, aspartate aminotransferase, alanine aminotransferase, gamma-glutamyl transferase, alkaline phosphatase, total and direct bilirubin and amylase, were also recorded.

The decision on LC timings was made entirely based on the surgeon's own planning or the severity of symptoms. All the surgeons who performed LC had extensive experience and a long learning curve. If the senior resident was performing the surgery, the decision to convert to open surgery was made after the intervention of the experienced surgeon. All surgical procedures were performed in a single center using a 4-port standard LC technique, and all patients received a single dose of prophylactic antibiotics on induction.

The time interval between ERCP and cholecystectomy was determined by calculating the time in days between the last ERCP and the day of surgery. To examine the effects of the time intervals, the patients were divided into three groups as follows: patients who underwent surgery within the first two weeks (Group I), patients who underwent surgery in between weeks two and six (Group 2) and patients who underwent surgery after $>6$ weeks (Group 3). Conversion from laparoscopic to open surgery and perioperative complications was investigated to be the primary outcome, and the effects of existing gallbladder pathology on the conversion from laparoscopic to open surgery was investigated as the secondary outcome. 


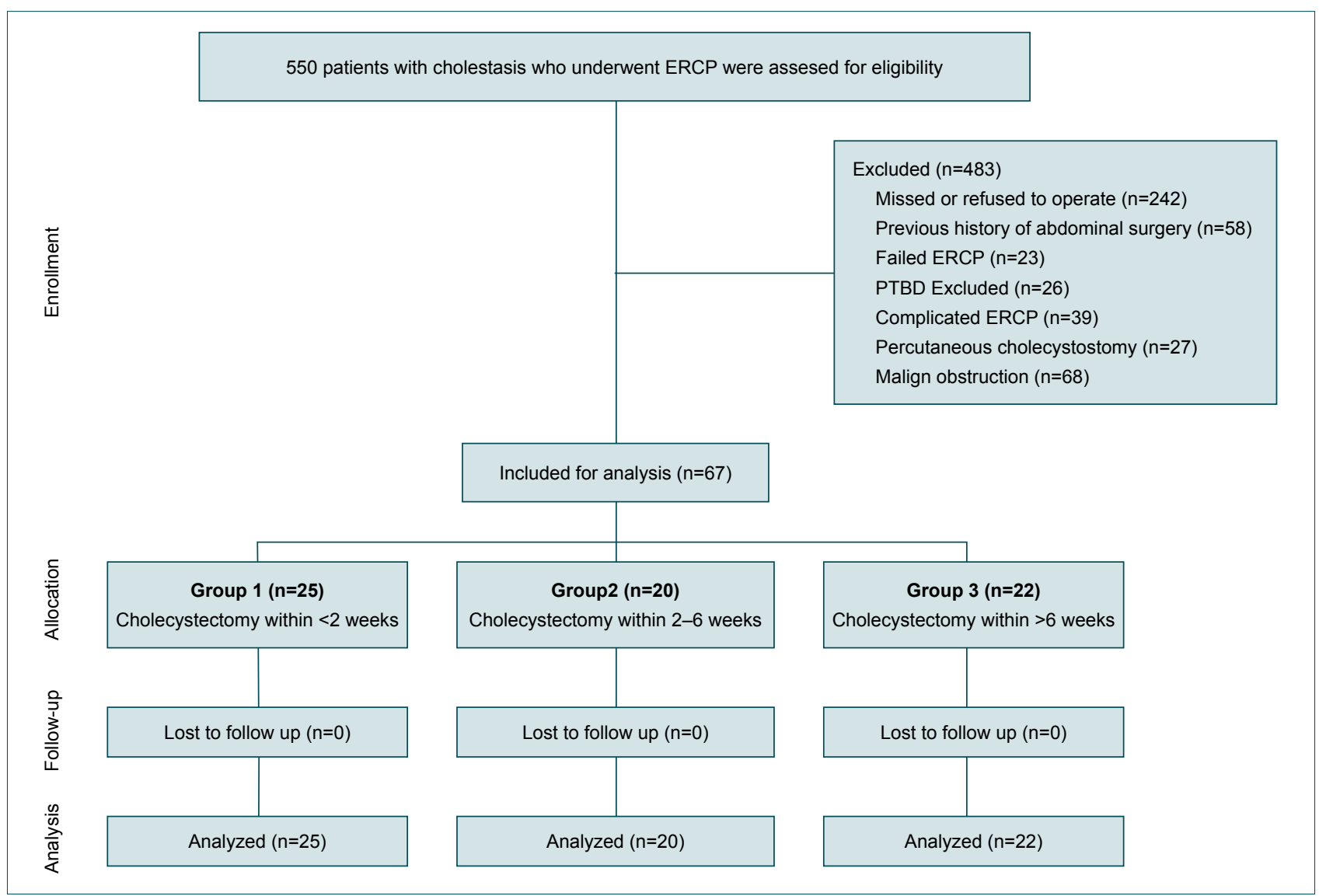

Figure 1. CONSORT flow diagram of this study. ERCP: Endoscopic retrograde cholangiopancreatography; ASA: American Society of Anesthesiologists.

\section{Statistical Analysis}

All statistical analyses were performed using Statistical Package for the Social Sciences version 20.0 for Windows $\left(\right.$ IBM $^{\circledR}$, Chicago, USA). Descriptive statistics were expressed as means and standard deviations in normally distributed numeric variables, as medians and interquartile ranges (IQRs) in non-normally distributed numeric variables, and as counts and percentages in categorical variables. Whether the variables were normally distributed was examined using visual (histograms and probability graphs) and analytical methods (Shapiro-Wilk tests). It was found that only the age variable was normally distributed, but the other variables were not. In intergroup comparisons, a One-Way ANOVA was preferred for age, and Kruskal Wallis tests were preferred for other variables that were not normally distributed. Bonferroni correction was preferred in post-hoc analyses. Intergroup analyses of categorical variables were carried out using the Chi-square method. For all analyses, a p-value of $<0.05$ was considered to indicate statistical significance.

\section{RESULTS}

Of the 550 patients who underwent consecutive ERCP during this study, only patients who underwent ERCP due to concurrent gallbladder and CBD stones were considered for eligibility.
A total of 67 patients were included in this study after accounting for the patients who were excluded from the study (Fig. I). LC after ERCP was performed between days 0 and 176.

Among the patients who were included in this study, 32 (47.8\%) were males, and 35 (52.2\%) were females with a mean age of $52.8 \pm 16.8$ years. Gender distribution was similar among the groups $(p=0.641)$. A statistically significant difference was found between the groups concerning age $(p=0.018)$, and this difference was between Groups 2 and 3 based on the post hoc analysis (44.8 vs. 59.3 years, $p=0.015$ ). Of the patients, 35 were in ASA category I or II, 19 were in ASA category III, and 13 patients were in ASA category IV. The majority of the patients undergoing ERCP due to biliary pancreatitis and the patients with comorbidity were in Groups I and 3. No differences were found between the groups concerning ASA classification $(p=0.102)$, presence of comorbidity $(p=0.083)$ and presence of pancreatitis $(p=0.408)$. However, it was seen that in patients with comorbidity and pancreatitis history, the tendency of the surgical team was to operate on the patients $(72.4 \%$ vs. $64.4 \%$, respectively) mainly in the late period. The demographic characteristics of the groups are shown in Table I.

Laboratory characteristics of the patients were found to be similar between groups. Gallbladder wall thickening was seen 
Table I. Baseline demographic data according to the time interval

\begin{tabular}{|c|c|c|c|c|}
\hline & $\begin{array}{c}\text { Group I }(n=25) \\
<2 \text { weeks }\end{array}$ & $\begin{array}{c}\text { Group } 2(n=20) \\
2-6 \text { weeks }\end{array}$ & $\begin{array}{c}\text { Group } 3(n=22) \\
>6 \text { weeks }\end{array}$ & $\mathbf{p}$ \\
\hline Age, mean $\pm S D$ (year) & $53.6 \pm 17.6$ & $44.8 \pm 14.8$ & $59.3 \pm 15.2$ & 0.018 \\
\hline Gender & & & & 0.641 \\
\hline Female & $13(52.0)$ & $12(60.0)$ & $10(45.5)$ & \\
\hline Male & $12(48.0)$ & $8(40.0)$ & $12(54.5)$ & \\
\hline ASA score & & & & 0.102 \\
\hline I & $5(20.0)$ & $8(40.0)$ & I (4.5) & \\
\hline II & $7(28.0)$ & $7(35.0)$ & $7(3 \mid .8)$ & \\
\hline III & $7(28.0)$ & $4(20.0)$ & $8(36.4)$ & \\
\hline IV & $6(24.0)$ & I (5.0) & $6(27.3)$ & \\
\hline Comorbidity $(+)$ & $16(64.4)$ & $8(40.0)$ & $16(72.7)$ & 0.083 \\
\hline Biliary pancreatitis $(+)$ & $4(16.0)$ & I (5.0) & $4(18.2)$ & 0.408 \\
\hline
\end{tabular}

ASA: American Society of Anesthesiologists; SD: Standard deviation.

Table 2. Comparison of the laboratory and preoperative radiological features

\begin{tabular}{|c|c|c|c|c|}
\hline & $\begin{array}{c}\text { Group I }(n=25) \\
<2 \text { weeks }\end{array}$ & $\begin{array}{c}\text { Group } 2(n=20) \\
2-6 \text { weeks }\end{array}$ & $\begin{array}{c}\text { Group } 3(n=22) \\
>6 \text { weeks }\end{array}$ & $\mathbf{p}$ \\
\hline Leucocyte $\left(10^{6} \times \mu \mathrm{L}\right)$ & $7.4(6.1-11.1)$ & $7.1(6.0-9.9)$ & $7.8(5.7-11.7)$ & 0.845 \\
\hline Serum AST (U/L) & $83(37-166)$ & $109(44-367)$ & $76(29-283)$ & 0.629 \\
\hline Serum ALT (U/L) & $204(68-298)$ & 154 (79-505) & $108(37-357)$ & 0.523 \\
\hline Serum ALP (U/L) & $179(126-215)$ & $184(15 \mid-385)$ & $159(120-343)$ & 0.324 \\
\hline Serum GGT (U/L) & $255(118-422)$ & $233(173-627)$ & $433(192-569)$ & 0.199 \\
\hline Total bilirubin (mg/dL) & $1.7(0.9-4.4)$ & $2.3(1.6-4.8)$ & $1.6(1.1-4.2)$ & 0.467 \\
\hline Direct bilirubin (mg/dL) & $0.4(0.3-2.7)$ & I.I $(0.4-3.0)$ & I.I (0.3-2.4) & 0.530 \\
\hline Serum amylase (U/L) & $132(58-239)$ & $63(50-98)$ & $68(45-197)$ & 0.117 \\
\hline Stone diameter $(\mathrm{mm})$ & I (I-9.5) & $I(I-I 2)$ & $12(1-20)$ & 0.379 \\
\hline Gallbladder wall thickness, $\mathrm{n}(\%)$ & & & & 0.960 \\
\hline$<4 \mathrm{~mm}$ & $21(84.0)$ & $17(85.0)$ & $18(81.8)$ & \\
\hline$\geq 4 \mathrm{~mm}$ & $4(16.0)$ & $3(15.0)$ & $4(18.2)$ & \\
\hline Gallbladder content, n (\%) & & & & 0.995 \\
\hline Sludge & II (44.0) & $9(45.0)$ & $10(45.5)$ & \\
\hline Stone & $14(56.0)$ & II (55.0) & $12(54.5)$ & \\
\hline
\end{tabular}

AST: Aspartate aminotransferase; ALT: Alanine aminotransferase; ALP: Alkaline phosphatase; GGT: Gamma-glutamyl transferase. All data except gallbladder thickness and content are reported as median (IQR), these data are number (\%).

in $16.0 \%(4 / 25)$ of the patients in Group I, $15.0 \%(3 / 20)$ of the patients in Group 2, and $18.2 \%(4 / 22)$ of the patients in Group $3(p=0.960)$. Moreover, the groups were similar concerning gallbladder content and median stone diameter $(p=0.995$ and $p=0.379$, respectively). The laboratory values and preoperative imaging results of the groups are shown in Table 2.

The total conversion rate was found to be $19.4 \%$ (13/67). The highest rate was in Group $2(25.0 \%, n=5)$, and the lowest was in Group 3 (13.6\%, n=3) (Fig. 2). However, no significant difference was detected between the groups in this regard $(p=0.646)$. Conversion from laparoscopic to open surgery took place in eight of the 32 male patients $(25.0 \%)$ and five of the 35 female patients (14.2\%). Median operating time was 80 min in Group I, 71 min in Group 2, and 75 min in Group 3. Median postoperative length of stay was three days in Group I, 2.5 days in Group 2, and four days in Group 3. However, no statistically significant differences were found between the groups regarding operating times or postoperative length of 


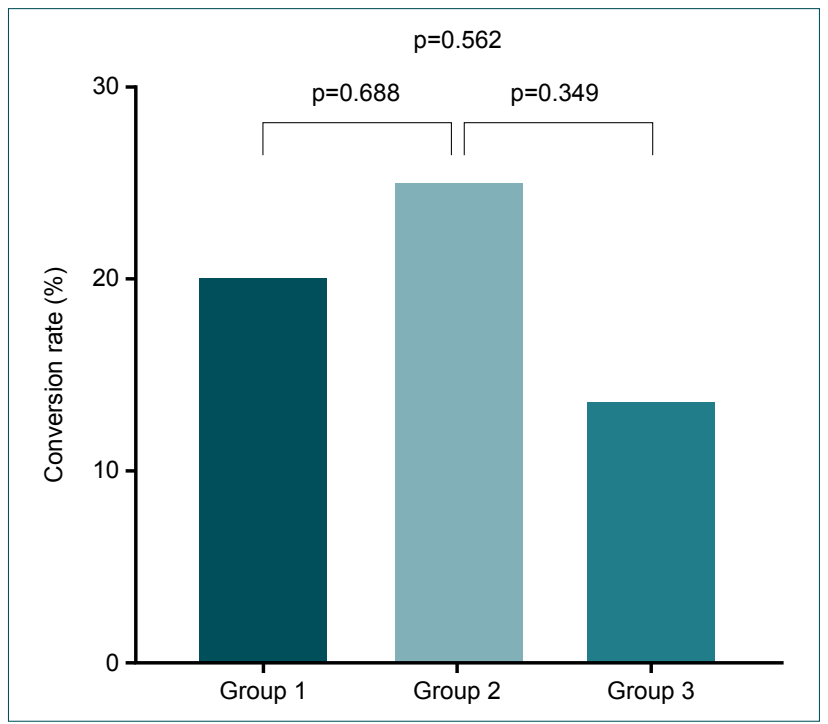

Figure 2. Conversion rates for time interval groups.

stay $(p=0.86 \mathrm{I}$ and $p=0.634$, respectively). Most complications were minor (Clavien-Dindo grade I), and there was no statistically significant difference between the groups concerning postoperative complications $(p=0.289)$. Overall ClavienDindo grade II and III complication rate was $17.9 \%$. In the group undergoing LC after $>6$ weeks, only two Clavien-Dindo grade III complications occurred. These complications were bile leaks from the cystic duct and managed with endoscopic interventions (Table 3).

When the patients who underwent conversion from laparoscopic surgery to open surgery were compared with the patients who were operated on fully laparoscopically, there was no difference between the groups concerning mean age $(p=0.698)$, gender $(p=0.268)$, preoperative gallbladder wall thickness $(p=0.911)$, gallbladder content $(p=0.176)$ and the median time interval between ERCP and LC $(p=0.284)$ (Table 4). Considering the reasons for conversion to open surgery, the main reason was anatomical ambiguity in $46.2 \%(n=6)$ of 13 patients, adhesion in $38.4 \%(n=5)$, and bleeding in $15.4 \%$ $(n=2)$. Bleeding was more pronounced in the early group, whereas adhesion was more pronounced in the late groups. There was no significant difference in the distribution of the reasons for conversion to open surgery among the groups $(p=0.582)$. No mortality was recorded in any of the groups (Table 5).

\section{DISCUSSION}

Patients with cholelithiasis and choledocholithiasis require treatment of both of these entities. ${ }^{[1,15,16]}$ Although there are several strategies for the treatment of combined choledochocystolithiasis, a commonly used strategy to treat patients is the two-stage management using preoperative ERCP with endoscopic sphincteroplasty and CBD stone removal followed by an interval LC. ${ }^{[3,9,17,18]}$ With the widespread adoption of laparoscopy, single-stage treatments, such as CBD exploration and LERV techniques, have evolved with LC. [4,7,13,17,19-21] The combination of LC and laparoscopic bile duct exploration (LBDE) allows for both removal of the gallbladder and treatment of CBD stones in the same stage. However, for LC and LBDE performed together in a single-stage, not only that a flexible choledochoscope is necessary together with a light source and a camera, and disposable instrumentations, such as baskets, balloons, and stents, but also that bile duct surgery is associated with a significant learning curve for both surgeons and staff. ${ }^{[4,8,10,20,22,23]}$ For this reason, a single-stage surgery may seem to be the ideal option for patients who undergo combined cholelithiasis and choledocholithiasis, but today, this treatment strategy cannot be implemented by many surgeons. In this case, surgeons usually prefer an interval LC as an option of treatment. However, this time interval be-

Table 3. Comparison of groups according to operative time, conversion rate, hospital stay, usage of the drain, and postoperative complications

\begin{tabular}{|c|c|c|c|c|}
\hline & $\begin{array}{c}\text { Group I }(n=25) \\
<2 \text { weeks }\end{array}$ & $\begin{array}{c}\text { Group } 2(n=20) \\
2-6 \text { weeks }\end{array}$ & $\begin{array}{c}\text { Group } 3(n=22) \\
>6 \text { weeks }\end{array}$ & $\mathbf{p}$ \\
\hline Type of operation, n (\%) & & & & 0.646 \\
\hline LC completed & $20(80.0)$ & I5 (75.0) & $19(86.4)$ & \\
\hline Conversion to $\mathrm{OC}$ & $5(20.0)$ & $5(25.0)$ & $3(13.6)$ & \\
\hline Operation time (min) & $80(60-120)$ & $71(60-101)$ & $75(68-96)$ & 0.861 \\
\hline Length of stay (day) & $3(I-6)$ & $2.5(I-5)$ & $4(2-5)$ & 0.634 \\
\hline Drain (+), n (\%) & $10(40.0)$ & $13(65.0)$ & $10(45.5)$ & 0.227 \\
\hline Clavien-Dindo classification, $\mathrm{n}(\%)$ & & & & 0.289 \\
\hline I & II (73.3) & $8(66.7)$ & $9(69.2)$ & \\
\hline II & $4(27.7)$ & $4(34.3)$ & $2(15.4)$ & \\
\hline III & 0 & 0 & $2(15.4)^{\mathrm{a}}$ & \\
\hline
\end{tabular}

LC: Laparoscopic cholecystectomy; OC: Open cholecystectomy. All data except operation time and length of stay are number (\%), these data are reported as median (IQR) abile leak from the cystic duct or stump. 
Table 4. Relationship between conversion to open and disease of the gallbladder

\begin{tabular}{|c|c|c|c|}
\hline & Full laparoscopic $(n=54)$ & Conversion to open $(n=13)$ & $\mathbf{p}$ \\
\hline Age, mean $\pm S D$ (year) & $52.5 \pm 17.1$ & $54.1 \pm 16.5$ & 0.698 \\
\hline Male, gender, n (\%) & $24(44.4)$ & $8(6 \mid .5)$ & 0.268 \\
\hline Gallbladder content, n (\%) & & & 0.176 \\
\hline Sludge & $22(40.7)$ & $8(61.5)$ & \\
\hline Stone & $32(59.3)$ & $5(38.5)$ & \\
\hline Gallbladder wall thickness, n (\%) & & & 0.911 \\
\hline Normal $(<4 \mathrm{~mm})$ & $45(83.3)$ & II (84.6) & \\
\hline Increased ( $\geq 4 \mathrm{~mm})$ & $9(16.7)$ & $2(15.4)$ & \\
\hline Time interval between ERCP and LC (day) & $77(60-100)$ & $72(60-120)$ & 0.284 \\
\hline
\end{tabular}

ERCP: Endoscopic retrograde cholangiopancreatography; LC: Laparoscopic cholecystectomy; SD: Standard deviation. Time interval between ERCP and LC are reported as median (IQR).

Table 5. Reason for conversion of laparoscopic cholecystectomy $(n=13)$

\begin{tabular}{lccccc}
\hline & Group I & Group 2 & Group 3 & $\mathbf{n}$ & $\%$ \\
\hline Adhesion & - & 3 & 2 & 5 & 38.4 \\
Hemorrhage & 2 & - & - & 2 & 15.4 \\
Anatomic & 3 & 2 & 1 & 6 & 46.2 \\
uncertainty & & & & & \\
Total & 5 & 5 & 3 & 13 & 100 \\
\hline
\end{tabular}

tween ERCP and LC ranges from days to months. ${ }^{[9,15,21]}$ When viewed from this perspective, there is a paradoxical problem that needs to be resolved because a single-stage operation requires experience, and a two-stage operation has the risk of leading to recurrent attacks and increased complication rates if not carried out within the appropriate time frame. In this study, we analyzed the intraoperative and postoperative outcomes of the patients undergoing LC at three different time intervals after emergent ERCP.

LC after ERCP with or without ES is a more complex procedure and is generally associated with a higher rate of conversion than standard LC with no previous intervention. ${ }^{[10,24,25]}$ Thus, the timing of LC after ERCP is a critical factor affecting the outcome. On the other hand, patients are at higher risk of RBE while waiting for a delayed cholecystectomy compared with patients who undergo an early cholecystectomy. [26] However, some surgeons tend to postpone the main surgical procedure of the patients who have previously undergone ERCP (a time interval of 6-8 weeks or more) to be able to perform cholecystectomy in an optimal condition, to allow the gallbladder area to cool off and the patients to recover from the acute illness and inflammation and at the end. ${ }^{[13]}$ Sometimes, surgical procedure is delayed for logistical reasons or choice of patients. ${ }^{[24]}$
It has been stated that the rate of conversion to open cholecystectomy is less than $5 \%$ after LC performed on uncomplicated gallbladder disease patients and that this rate varies between $8-55 \%$ after ERCP. ${ }^{[13,17,27]}$ The cause of such high conversion rates is explained by that post-ES bile reflux and bacterial contamination cause inflammation and adhesions around the Calot's triangle and gallbladder. ${ }^{[12,25,28]}$ In a study comparing the optimal time to achieve a better outcome, de Vries et al. ${ }^{[9]}$ found a higher rate of conversion (31\%) in patients undergoing LC 2-6 weeks after the ERCP procedure. They determined that the conversion rate was $4 \%$ in patients undergoing LC in the first two weeks after ERCP, and the rate was $16 \%$ after $>6$ weeks. They found that there was a significant difference concerning the rate of conversion between the patients who were operated on in the first two weeks after ERCP and patients who were operated on in 2-6 weeks after ERCP. However, the severity of adhesions encountered during the procedures, bile duct injury, and the time needed to perform the LC were not found to be influenced by the interval between ERCP and LC. Similarly, Bostanci et al. ${ }^{\left[{ }^{1}\right]}$ found that the higher conversion rates were not associated with the time interval between ERCP and LC or with the performance of stone extraction during ERCP. These rates were found to be associated with the number of ERCPs performed before surgery. In another study conducted by Salman et al., ${ }^{[12]}$ patients were divided into two groups - patients who underwent LC 24-72 hours after ERCP and patients who underwent surgery 72 hours -7 days after ERCP - and the conversion rate was found to be statistically significant in the delayed LC group compared to the early LC group (I7.5\% vs. $2.5 \%$, respectively, $p=0.02$ ). A recent systematic review conducted by Friis et al. ${ }^{[29]}$ showed an increase from a $4.2 \%$ conversion rate when LC was performed within $24 \mathrm{~h}$ of ERCP to $7.6 \%$ when performed after $24-72 \mathrm{~h}$ delay, to $12.3 \%$ when performed within two weeks and 2-6 weeks, and to a $14 \%$ conversion rate when the operation was performed more than six weeks after ERCP. The authors suggested that chole- 
cystectomy can be carried out safely within the first 24-72 $h$ of ERCP to reduce the conversion rate and perioperative complications.

Although the time interval between ERCP and cholecystectomy has been described as early or delayed, the definitions of "early" or "delayed" differ across studies. In many studies, early cholecystectomy has been defined as an operation within two or three days after ERCP, whereas in some others, it has been defined as an operation within two weeks of ERCP. Moreover, late cholecystectomy definitions vary to include 2-8 weeks after ERCP. Apart from the studies in which patients were divided into patients undergoing early and late cholecystectomy, in many other studies, these intervals were studied by being divided into three different time intervals. Moreover, patients' inclusion and exclusion criteria had high heterogeneity. In the current study, the patients were divided into three groups to cover all time intervals as patients who underwent surgery within the first two weeks, patients who underwent surgery 2-6 weeks, and patients who underwent surgery after $>6$ weeks. Overall, the rate of conversion to open laparotomy was $19.4 \%$, and this rate is comparable with the larger series. The highest conversion rate was in the group of patients who were operated on 2-6 weeks after ERCP (25.0\%), and the lowest conversation was in the group of patients who were operated on six weeks after ERCP (13.6\%). The results of this study suggested that the time interval from the ERCP procedure to LC was not a significant factor for conversion to open cholecystectomy. Although there was no statistically significant difference in the rates, conversion to open surgery took place at all-time intervals. However, it was seen that the subacute period after ERCP was a more critical time frame for conversion to open surgery.

Many studies have not specified any difference between groups concerning the rates of conversion to open surgery, but they have shown results showing the advantages of early cholecystectomy concerning other factors. El Nakeeb et al. ${ }^{[28]}$ conducted a study by dividing patients into two groups as early LC (within three days after ERCP) and late LC (one month after ERCP). They found no difference between the groups concerning the conversion rate. However, recurrent biliary symptoms and morbidity rates were found to be significantly higher in the late LC group than in the early group. Similarly, Reinders et al. ${ }^{[13]}$ reported that the conversion rate, postoperative complications, hospital stay, and postoperative pain were comparable between groups. They also showed that early LC was likely to minimize the risk of RBE compared with delayed LC. Kwon et al. ${ }^{[17]}$ designed a study to evaluate a total of 305 patients who underwent cholecystectomy after ERCP, where they found the rate of conversion to open cholecystectomy as $15.7 \%$. The rate was $14.5 \%<2$ weeks after ERCP, 18.4\% 2-6 weeks after ERCP, and 15.6\% >6 weeks after ERCP. In their study, in which the period between ERCP and surgery was divided into three groups, they found no statistical difference in the conversion rate among different time intervals. They revealed that cholecystitis (OR I.90), mechanical lithotripsy (OR 6.I3), and two or more CBD stones (OR 2.20) were significant risk factors for conversion to open cholecystectomy. In a recent study, Aziret et al. ${ }^{[30]}$ examined the time interval between ERCP and LC in three groups as early (48-72 h), moderate (72 h-6 weeks), and delayed (6-8 weeks). They showed that the early LC was associated with shorter operation time, lesser hospital readmissions, fewer fibrotic changes in the gallbladder, and lower complication rates, but not with conversion rates.

In this study, the time interval from ERCP to LC was not a significant factor for postoperative complications, operation time, drain usage, or length of hospital stay. Conversion to open surgery was higher in male patients than in female patients $(25.0 \%$ vs. $14.2 \%)$, indicating that LC is more difficult and is a risk factor for conversion to open surgery in male patients. One of the important findings of the current study was that the patients in Group 3 ( $>6$ weeks after ERCP) were older (mean age 59.3 years) $(p=0.018)$, and their accompanying comorbidity rates were higher than in other groups, indicating that patient-related factors were an effective factor on the time interval. No difference was found among the patients who were transitioned to open surgery and patients who were operated fully laparoscopically concerning age, gender, gallbladder wall thickness or content, and time interval, supporting the idea that not only the time interval but also patient-related or procedural factors, such as concomitant cholangitis, cholecystitis, pancreatitis, stent insertion, and the number of procedures can play a more effective role in the conversion to open surgery.

Some authors found that among patients who undergo LC, preoperative ERCP might be associated with more common intra- and post-operative complications according to time intervals. Another point that stood out in the studies that were examined was that there were differences regarding the incidence of complications, such as perioperative uncontrolled bleeding, gallbladder rupture, CBD injury and bile leakage from the bed or the cystic stump concerning time intervals after ERCP. ${ }^{[9,11,30]}$ Beliaev et al. ${ }^{[15]}$ conducted a study examining the effects of LCs performed at different time intervals after ERCP on the ratio of major bile duct injuries, where the late ( $\geq 16$ weeks) LC was found to be associated with a 10 -fold increase in major bile duct injuries. In our study, there was no statistically significant difference in perioperative complications among the patients who underwent LC >2 weeks, 2-6 weeks and $>6$ weeks after ERCP. The rate of Clavien-Dindo grade II and III complications was 17.9\% (I 2 of 67 patients). Concerning major complications, two patients in the group undergoing LC after $>6$ weeks developed Clavien-Dindo grade III complications. These were bile leaks from the cystic duct and were managed with endoscopic interventions. The procedure is completed through laparoscopic subtotal cholecystectomy, and there may be more bile leaks from the cystic stump due also to the high prevalence of adhesions in the late group. 
Thus, serious bile duct problems may occur. For this reason, it has been recommended that the surgery be performed by an experienced laparoscopic surgeon to reduce both conversion rates and complications in LC performed after ERCP.

Single-stage treatment (LBDE during LC) clearly has the advantage of the immediate treatment of both $\mathrm{CBD}$ stones and cholelithiasis. However, because of the lack of experienced surgeons or organizational restrictions, delayed LC is often chosen as the standard treatment of patients who have gallbladder and $\mathrm{CBD}$ stones and have undergone ERCP in many European countries as well as our country. ${ }^{[1,24,26]}$ In this situation, another main problem that emerges is RBEs waiting to undergo surgery. In our study, the results suggest that none of the time intervals was superior to the others regarding the conversion rates and postoperative complications. This may be because all surgical procedures were performed or supervised by experienced surgeons or due to appropriate patient selection. However, this study has several limitations. First, because of the retrospective nature of this study, the data were collected from the surgical reports and patients' file. Second, this study comprises a small sample size; however, we believe that this study can provide new insights into the literature compared to the effects of different time intervals between ERCP and LC. In addition, there are limited data regarding the number of biliary cannulations during ERCP. Finally, we did not evaluate the RBEs occurring in the interval between ERCP and cholecystectomy.

In conclusion, our results support the notion that $\mathrm{LC}$ after an ERCP procedure is more complex and difficult and has higher conversion rates than LC for uncomplicated cholelithiasis. In this retrospective analysis, although no significant effect of different time intervals between ERCP and LC on perioperative outcomes was demonstrated in patients with $C B D$ stones concomitant with cholelithiasis, the subacute period after ERCP is a critical period of time to convert to open surgery. Considering that serious complications may develop in the late period and RBEs may take place, LC after ERCP is recommended to be performed in the early period. It is possible to reduce conversion rates and complications only by considering the time interval only if surgeries are performed by advanced laparoscopic surgeons. For more accurate results, it is necessary to conduct more prospective studies where patients are randomly evaluated, and time intervals are determined by sharp limits.

Ethics Committee Approval: This study was approved by Gulhane Military Medical Academy Ethics Committee (approval number: 50687469-149I-146-16/1648-436) and was conducted in accordance with the 1964 Helsinki Declaration and its later amendments.

Peer-review: Internally peer-reviewed.

Authorship Contributions: Concept: R.Ş., Ş.K., O.H.; Design: R.Ş., S.U.Ç., Ş.K., O.H.; Supervision: R.Ş.; Fundings: R.Ş., S.U.Ç., Ş.K., O.H.; Materials: R.Ş., S..K.; Data: R.Ş., Ş.K., O.H;
Analysis: R.Ş., S.U.Ç.; Literature search: R.Ş., S.U.Ç.; Writing: R.Ş., S.U.Ç.; Critical revision: R.Ş., S.U.Ç., Ş.K., O.H.

Conflict of Interest: None declared.

Financial Disclosure: This research did not receive any specific grant from funding agencies in the public, commercial, or not-for-profit sectors.

\section{REFERENCES}

1. Mutha P, Shah T, Heuman D, Zfass A, Schubert ML. Choledocholithiasis Without Cholelithiasis: Should the Gallbladder Stay or Should It Go?. Dig Dis Sci 2016;61:961-2. [CrossRef]

2. Dasari BV, Tan CJ, Gurusamy KS, Martin DJ, Kirk G, McKie L, et al. Surgical versus endoscopic treatment of bile duct stones. Cochrane Database Syst Rev 2013;(9):CD003327. [CrossRef]

3. Clayton ES, Connor S, Alexakis N, Leandros E. Meta-analysis of endoscopy and surgery versus surgery alone for common bile duct stones with the gallbladder in situ. Br J Surg 2006;93:1185-91. [CrossRef]

4. Morino M, Baracchi F, Miglietta C, Furlan N, Ragona R, Garbarini A. Preoperative endoscopic sphincterotomy versus laparoendoscopic rendezvous in patients with gallbladder and bile duct stones. Ann Surg 2006;244:889-96. [CrossRef]

5. Taylor EW, Rajgopal U, Festekjian J. The efficacy of preoperative endoscopic retrograde cholangiopancreatography in the detection and clearance of choledocholithiasis. JSLS 2000;4:109-16.

6. Zargar SA, Mushtaq M, Beg MA, Javaid G, Khan BA, Hassan R,et al. Wait-and-see policy versus cholecystectomy after endoscopic sphincterotomy for bile-duct stones in high-risk patients with co-existing gallbladder stones: a prospective randomised trial. Arab J Gastroenterol 2014;15:24-6. [CrossRef]

7. de Mestral C, Rotstein OD, Laupacis A, Hoch JS, Zagorski B, Alali AS, et al. Comparative operative outcomes of early and delayed cholecystectomy for acute cholecystitis: a population-based propensity score analysis. Ann Surg 2014;259:10-5. [CrossRef]

8. da Costa DW, Bouwense SA, Schepers NJ, Besselink MG, van Santvoort HC, van Brunschot S, et al; Dutch Pancreatitis Study Group. Sameadmission versus interval cholecystectomy for mild gallstone pancreatitis (PONCHO): a multicentre randomised controlled trial. Lancet 2015;386:1261-8.

9. de Vries A, Donkervoort SC, van Geloven AA, Pierik EG. Conversion rate of laparoscopic cholecystectomy after endoscopic retrograde cholangiography in the treatment of choledocholithiasis: does the time interval matter?. Surg Endosc 2005;19:996-1001. [CrossRef]

10. Sarli L, Iusco DR, Roncoroni L. Preoperative endoscopic sphincterotomy and laparoscopic cholecystectomy for the management of cholecystocholedocholithiasis: 10-year experience. World J Surg 2003;27:180-6.

11. Bostanci EB, Ercan M, Ozer I, Teke Z, Parlak E, Akoglu M. Timing of elective laparoscopic cholecystectomy after endoscopic retrograde cholangiopancreaticography with sphincterotomy: a prospective observational study of 308 patients. Langenbecks Arch Surg 2010;395:661-6. [CrossRef]

12. Salman B, Yilmaz U, Kerem M, Bedirli A, Sare M, Sakrak O, et al. The timing of laparoscopic cholecystectomy after endoscopic retrograde cholangiopancreaticography in cholelithiasis coexisting with choledocholithiasis. J Hepatobiliary Pancreat Surg 2009;16:832-6. [CrossRef]

13. Reinders JS, Goud A, Timmer R, Kruyt PM, Witteman BJ, Smakman $\mathrm{N}$, et al. Early laparoscopic cholecystectomy improves outcomes after endoscopic sphincterotomy for choledochocystolithiasis. Gastroenterology 2010;138:2315-20. [CrossRef] 
14. Dindo D, Demartines N, Clavien PA. Classification of surgical complications: a new proposal with evaluation in a cohort of 6336 patients and results of a survey. Ann Surg 2004;240:205-13. [CrossRef]

15. Beliaev AM, Booth M. Late two-stage laparoscopic cholecystectomy is associated with an increased risk of major bile duct injury. ANZ J Surg 2016;86:63-8. [CrossRef]

16. Trejo-Ávila M, Solórzano-Vicuña D, García-Corral R, Bada-Yllán O, Cuendis-Velázquez A, Delano-Alonso R, et al. Laparoscopic cholecystectomy after endoscopic treatment of choledocholithiasis: a retrospective comparative study. Updates Surg 2019;71:669-75. [CrossRef]

17. Kwon YH, Cho CM, Jung MK, Kim SG, Yoon YK. Risk factors of open converted cholecystectomy for cholelithiasis after endoscopic removal of choledocholithiasis. Dig Dis Sci 2015;60:550-6. [CrossRef]

18. Williams E, Beckingham I, El Sayed G, Gurusamy K, Sturgess R, Webster $\mathrm{G}$, et al. Updated guideline on the management of common bile duct stones (CBDS). Gut 2017;66:765-82. [CrossRef]

19. Saccomani G, Durante V, Magnolia MR, Ghezzo L, Lombezzi R, Esercizio L, et al. Combined endoscopic treatment for cholelithiasis associated with choledocholithiasis. Surg Endosc 2005;19:910-4. [CrossRef]

20. Mo LR, Chang KK, Wang CH, Yau MP, Yang TM. Preoperative endoscopic sphincterotomy in the treatment of patients with cholecystocholedocholithiasis. J Hepatobiliary Pancreat Surg 2002;9:191-5. [CrossRef]

21. Schiphorst AH, Besselink MG, Boerma D, Timmer R, Wiezer MJ, van Erpecum KJ, et al. Timing of cholecystectomy after endoscopic sphincterotomy for common bile duct stones. Surg Endosc 2008;22:2046-50.

22. Martin DJ, Vernon DR, Toouli J. Surgical versus endoscopic treatment of bile duct stones. Cochrane Database Syst Rev 2006;(2):CD003327.

23. Vettoretto N, Arezzo A, Famiglietti F, Cirocchi R, Moja L, Morino M. Laparoscopic-endoscopic rendezvous versus preoperative endoscopic sphincterotomy in people undergoing laparoscopic cholecystectomy for stones in the gallbladder and bile duct. Cochrane Database Syst Rev 2018;4:CD010507. [CrossRef]

24. Manes G, Paspatis G, Aabakken L, Anderloni A, Arvanitakis M, AhSoune P, et al. Endoscopic management of common bile duct stones: European Society of Gastrointestinal Endoscopy (ESGE) guideline. Endoscopy 2019;51:472-91. [CrossRef]

25. Reinders JS, Gouma DJ, Heisterkamp J, Tromp E, van Ramshorst B, Boerma D. Laparoscopic cholecystectomy is more difficult after a previous endoscopic retrograde cholangiography. HPB (Oxford) 2013;15:230-4.

26. Huang RJ, Barakat MT, Girotra M, Banerjee S. Practice Patterns for Cholecystectomy After Endoscopic Retrograde Cholangiopancreatography for Patients With Choledocholithiasis. Gastroenterology 2017;153:762-71.e2. [CrossRef]

27. Genc V, Sulaimanov M, Cipe G, Basceken SI, Erverdi N, Gurel M, et al. What necessitates the conversion to open cholecystectomy? A retrospective analysis of 5164 consecutive laparoscopic operations. Clinics (Sao Paulo) 2011;66:417-20. [CrossRef]

28. El Nakeeb A, Ezzet H, Askar W, El Hanafy E, Hamdy E, Atef E, et al. Early Versus Late Cholecystectomy After Clearance of Common Bile Duct Stones by Endoscopic Retrograde Cholangiopancreatography: A Prospective Randomized Study. Surg Laparosc Endosc Percutan Tech 2016;26:202-7. [CrossRef]

29. Friis C, Rothman JP, Burcharth J, Rosenberg J. Optimal Timing for Laparoscopic Cholecystectomy After Endoscopic Retrograde Cholangiopancreatography: A Systematic Review. Scand J Surg 2018;107:99106. [CrossRef]

30. Aziret M, Karaman K, Ercan M, Vargöl E, Toka B, Arslan Y, et al. Early laparoscopic cholecystectomy is associated with less risk of complications after the removal of common bile duct stones by endoscopic retrograde cholangiopancreatography. Turk J Gastroenterol 2019;30:336-44.

\section{ORIJIINAL ÇALIŞMA - ÖZET}

\section{Safra kanalı taşları için yapılan acil endoskopik retrograd kolanjiyopankreatografi sonrası laparoskopik kolesistektomi uygulanan hastaların perioperatif sonuçları: Zamanlama önemli mi?}

\section{Dr. Rahman Şenocak, Dr. Süleyman Utku Çelik, Dr. Şahin Kaymak, Dr. Oğuz Hançerlioğulları}

Sağlık Bilimleri Üniversitesi Gülhane Eğitim ve Araştırma Hastanesi, Genel Cerrahi Kliniği, Ankara

AMAÇ: Koledokolitiyazis nedeni ile acil endoskopik retrograd kolanjiyopankreatografi (ERCP) yapılan hastalarda laparoskopik kolesistektomi (LK) için optimal zamanlama konusunda fikir birliği yoktur. Her ne kadar bazı veriler erken dönemde cerrahinin veya tek aşamalı LK ile birlikte yapılan laparoskopik safra kanalı eksplorasyonunun daha olumlu sonuçlara sahip olduğunu düşündürse de deneyim eksikliği, gerekli malzeme yokluğu veya klinik kısıtlılıklar nedeniyle geç dönem LK çoğunlukla ERCP sonrası sebat eden safra taşı olan hastaların standart tedavisi olarak tercih edilmektedir. Bu çalışmanın amacı, ERCP ve LK arasındaki farklı zaman aralıklarının perioperatif sonuçlar üzerindeki etkilerini değerlendirmektir.

GEREÇ VE YÖNTEM: ERCP ile ana safra kanalı taşları tedavi edilen ve daha sonra LK uygulanan ardışık hastaların ameliyat öncesi ve sonrası verileri geriye dönük olarak incelendi. Farklı zaman aralıklarının sonuçlar üzerindeki etkisini değerlendirmek için hastalar son yapılan ERCP'den LK'ye kadar geçen süreye göre üç gruba ayrıldı: 2 hafta içinde (Grup I), 2-6 hafta arasında (Grup 2) ve 6 haftadan sonra (Grup 3).

BULGULAR: Bu çalışmada ortalama yaşı 52.8 olan toplam 67 hasta analiz edildi. Olguların kapalı ameliyattan açığa geçme oranı Grup I'de \%20, Grup 2'de \%25 ve Grup 3'te \%।3.6 idi ( $p=0.646)$. Bu oran erkek hastalarda \%25 ve kadınlarda ise \% 4.2 olarak hesaplandı. Gruplar arasında cinsiyet, yandaş hastalık, laboratuvar ve safra kesesi özellikleri, ameliyat süresi ve hastanede kalış süresi açısından anlamlı fark bulunmadı. Perioperatif komplikasyon oranı \% 17.9 bulundu; ancak gruplar arasında komplikasyon oranı açısından anlamlı fark saptanmadı $(p=0.289)$.

TARTIŞMA: Bu çalışmadan elde edilen sonuçlar, ERCP sonrası yapılan LK'nin komplike olmayan standart kolelitiazis için yapılan LK'den daha kompleks ve daha yüksek açığa geçiş oranına sahip olduğunu desteklemektedir. Kolelitiazise eşlik eden ana safra kanalı taşları olan hastalarda ERCP sonrasında farklı zaman aralığında uygulanan LK'nin perioperatif sonuçlar üzerinde anlamlı bir etkisi görülmemesine rağmen, LK'nin açık cerrahiye geçmesi açısından ERCP'den sonraki 2-6 hafta kritik bir dönemdir. Ayrıca geç dönemde yapılan LK'de ciddi komplikasyonların ortaya çıkabileceği ve tekrarlayan biliyer atakların olabileceği göz önünde bulundurulduğunda ERCP sonrası LK'nin erken dönemlerde yapılması önerilir. Anahtar sözcükler: Endoskopik retrograd kolanjiyopankreatografi; koledokolitiazis; kolelitiazis; komplikasyon; laparoskopik kolesistektomi.

Ulus Travma Acil Cerrahi Derg 2020;26(3):396-404 doi: 10.14744/tjtes.2020.9440। 